\title{
Rubella Immune Status in Pregnant Women in a Northern Mexican City
}

\author{
Cosme Alvarado-Esquivel ${ }^{\mathrm{a}, \mathrm{d}}$, Jesus Hernandez-Tinoco ${ }^{\mathrm{b}}$, Luis Francisco Sanchez-Anguiano ${ }^{\mathrm{b}}$, \\ Agar Ramos-Nevarez ${ }^{c}$, Sandra Margarita Cerrillo-Soto ${ }^{c}$, Jose Manuel Salas-Pacheco ${ }^{b}$, \\ Ada Agustina Sandoval-Carrillo ${ }^{b}$, Lucio Martinez-Ramirez ${ }^{c}$, Elizabeth Irasema Antuna-Salcido ${ }^{\mathrm{b}}$, \\ Carlos Alberto Guido-Arreola ${ }^{\mathrm{c}}$
}

\begin{abstract}
Background: The seroepidemiology of rubella virus infection in pregnant women in northern Mexico is largely unknown. We sought to determine the seroprevalence of rubella virus infection in pregnant women in the northern Mexican city of Durango, Mexico. Seroprevalence association with the socio-demographic, clinical and behavioral characteristics of the pregnant women was also investigated.
\end{abstract}

Methods: Through a cross-sectional study, we determined the seroprevalence of $\operatorname{IgG}$ and IgM anti-rubella virus in 279 pregnant women (mean age $29.17 \pm 5.96$ years; range $15-43$ years) attending in a clinic of family medicine using enzyme-linked fluorescent assays. A questionnaire was used to obtain the socio-demographic, clinical and behavioral characteristics of the pregnant women. The association of rubella seropositivity and characteristics of the women was assessed by bivariate and multivariate analyses.

Results: Anti-rubella IgG antibodies $(\geq 15 \mathrm{IU} / \mathrm{mL})$ were found in 271 (97.1\%) of the 279 pregnant women examined. None of the 279 pregnant women were positive for anti-rubella IgM antibodies. Multivariate analysis of socio-demographic, clinical and behavioral variables showed that seroreactivity to rubella virus was positively associated with national trips $(\mathrm{OR}=7.39 ; 95 \% \mathrm{CI}: 1.41-38.78 ; \mathrm{P}=0.01)$, and negatively associated with age $(\mathrm{OR}=0.26 ; 95 \% \mathrm{CI}: 0.06-0.99 ; \mathrm{P}=$ $0.04)$.

Conclusions: Rate of rubella immunity in pregnant women in the northern Mexican city of Durango is high. However, nearly 3\% of pregnant women are susceptible to rubella in our setting. Risk fac-

Manuscript accepted for publication July 05, 2016

aBiomedical Research Laboratory, Faculty of Medicine and Nutrition, Juarez University of Durango State, Avenida Universidad S/N, 34000 Durango, Mexico

bInstitute for Scientific Research "Dr. Roberto Rivera-Damm", Juarez University of Durango State, Avenida Universidad S/N, 34000 Durango, Mexico ${ }^{\mathrm{c}}$ Clinica de Medicina Familiar, Instituto de Seguridad y Servicios Sociales de los Trabajadores del Estado, Predio Canoas S/N, 34079 Durango, Mexico ${ }^{\mathrm{d} C}$ Corresponding Author: Cosme Alvarado-Esquivel, Laboratorio de Investigacion Biomedica, Facultad de Medicina y Nutricion, Avenida Universidad S/N, 34000 Durango, Dgo, Mexico. Email: alvaradocosme@yahoo.com

doi: http://dx.doi.org/10.14740/jocmr2635w tors associated with rubella seropositivity found in this study may be useful for optimal design of preventive measures against rubella and its sequelae.

Keywords: Rubella; Pregnant women; Epidemiology; Seroprevalence; Cross-sectional study; Mexico

\section{Introduction}

Rubella virus is a single-stranded ribonucleic acid virus of the Togaviridae family $[1,2]$, and is a sole member of the genus Rubivirus [3]. Infection with rubella virus occurs by inhalation of contaminated droplets [1], and can be vertically transmitted to fetuses during maternal infection leading to congenital infection [4]. Rubella virus is an important pathogen worldwide [5]. Infection with rubella virus causes a febrile rash illness in children and adults [6]. In addition, infection with rubella virus in adults may cause severe inflammation and pain in the joints [1]. However, infection with rubella virus during the first trimester of pregnancy can lead to prematurity, low birth weight [7], miscarriage, stillbirth [6], and congenital rubella syndrome $[6,8]$. This syndrome is characterized by fetal anomalies including mental retardation [9], heart defects, cataracts [8], blindness, deafness [9], and hepatomegaly and jaundice [10]. There is not currently antiviral treatment for rubella [1]. An effective and sure vaccine against rubella is available [1, 5]. However, rubella outbreaks in Japan and other countries have been reported recently $[2,5,11]$.

The seroepidemiology of rubella virus infection in Mexican populations has been scantily studied. An $87 \%$ seroprevalence of anti-rubella antibodies in puerperal women from Delicias City in the northern Mexican city of Chihuahua was reported [12], whereas a 92.6\% seroprevalence of rubella virus infection in pregnant women in two zones of the valley of Mexico was found [13]. In a study in Leon, Guanajuato, Mexico, researchers found a $71 \%$ seroprevalence of rubella in 176 women at reproductive age [14]. To the best of our knowledge, there is not any study on the seroepidemiology of rubella virus infection in pregnant women in northern Mexico. Therefore, this study was aimed to determine the seroprevalence of rubella virus infection in pregnant women in the northern Mexican city of Durango, Mexico. Furthermore, rubella seroprevalence 
association with the socio-demographic, clinical and behavioral characteristics of the pregnant women was also assessed.

\section{Materials and Methods}

\section{Study design and population}

We performed a cross-sectional study using stored serum samples from a previous survey of cytomegalovirus infection in pregnant women in Durango City, Mexico [15]. Samples were originally obtained to determine the seroprevalence of anticytomegalovirus antibodies in pregnant women attending a public primary health care center (Clinic of Family Medicine, Institute of Security and Social Services of State Workers) in Durango City, Mexico. Serum samples were obtained from April to November 2013. Inclusion criteria for enrollment of the participants were: 1) pregnant women attending prenatal care; 2) aged 15 years and older; 3) residence in Durango City; and 4) who voluntarily accepted to participate in the survey.

\section{Socio-demographic, clinical and behavioral characteris- tics of participants}

We obtained the socio-demographic, clinical and behavioral characteristics from the participants with the aid of a questionnaire. Socio-demographic items included age, birthplace, residence, educational level, occupation and socio-economic status. Clinical items included health status, history of lymphadenopathy, frequent headaches; impairments of memory, vision and hearing; and history of blood transfusions. In addition, the obstetric history (month of pregnancy, number of pregnancies, deliveries, cesarean sections and miscarriages) from each participant was recorded. Behavioral items included foreign traveling, alcohol consumption, tobacco use, and washing hands before eating.

\section{Laboratory tests}

Sera of the participants were kept frozen until analyzed. Sera were examined for anti-rubella IgG antibodies by a commercially available enzyme-linked fluorescent assay (ELFA) "VIDAS RUB IgG II" kit (bioMerieux SA, Marcy-l'Etoile, France) and for anti-rubella IgM antibodies by a commercially ELFA "VIDAS RUB IgM" kit (bioMerieux SA, Marcyl'Etoile, France). Anti-rubella IgG antibody levels of $\geq 15$ IU/ $\mathrm{mL}$ were considered as a cut-off for seropositivity. This titer suggests protection against rubella $[16,17]$. All tests were performed according to the manufacturer's instructions.

\section{Ethical aspects}

This study was performed using stored serum samples from a previous survey. In such previous study, the purpose and procedures of the study were explained to all participants, and a written informed consent was obtained from all of them and from the next of kin of minor participants. The ethical committee of the Institute of Security and Social Services of State Workers in Durango City, Mexico approved this study.

\section{Statistical analysis}

Results were analyzed with the aid of the Epi Info version 7 and SPSS version 15.0 software. For calculation of the sample size, we used a value of 15,000 as a population size from which the sample was selected, a reference seroprevalence of $87.0 \%$ [12] as expected frequency of the factor under study, $5.0 \%$ of confidence limits, a design effect of 1.0 , one cluster, and a confidence level of $95 \%$. The result of the calculation was 172 subjects. We evaluated the association between the characteristics of the women and rubella seropositivity by using bivariate and multivariate analyses. For comparison of the frequencies among groups, the Pearson's Chi-square and the Fisher exact test (when values were less than 5) were used. As a strategy to include variables in the multivariate analysis, we selected only variables with a $P$ value equal to or less than 0.05 obtained in the bivariate analysis. We calculated the odds ratios (ORs) and 95\% confidence intervals (CIs) by multivariate analysis using the Enter method. Statistical significance was set at a $\mathrm{P}$ value $<0.05$.

\section{Results}

We enrolled a total of 279 pregnant women. Their mean age was $29.17 \pm 5.96$ years (range 15 - 43 years). Table 1 shows the general socio-demographic characteristics of the pregnant women studied. Anti-rubella IgG antibodies were found in $271(97.1 \%)$ of the 279 pregnant women examined. None of the 279 pregnant women were positive for anti-rubella IgM antibodies. Of the socio-demographic characteristics of the pregnant women, the variables including age group and socioeconomic status were associated with anti-rubella IgG antibodies by bivariate analysis, whereas the variables including birthplace, residence, educational level, and occupation did not associate with anti-rubella IgG antibodies.

With respect to clinical characteristics, rubella seroprevalence was similar in ill and healthy pregnant women. Table 2 shows a correlation of rubella seroprevalence and clinical characteristics of pregnant women. Rubella seroprevalence was significantly $(\mathrm{P}=0.02)$ higher in pregnant women with frequent headaches, whereas women with history of deliveries had a higher (borderline significance: $\mathrm{P}=0.05$ ) rubella seroprevalence than women without this history. Other clinical characteristics of women including history of lymphadenopathy, impairments of memory, vision and hearing; history of blood transfusions, month of pregnancy, number of pregnancies, deliveries, cesarean sections and miscarriages did not show an association with rubella seroprevalence by bivariate analysis.

Concerning behavioral characteristics of women, the variable "national trips" showed a borderline $(\mathrm{P}=0.05)$ association with rubella seroprevalence. Other behavioral characteristics 
Table 1. Socio-Demographic Characteristics of Pregnant Women and Seroprevalence of Rubella IgG Antibodies ( $\geq 15 \mathrm{IU} / \mathrm{mL}$ )

\begin{tabular}{|c|c|c|c|c|}
\hline \multirow{2}{*}{ Characteristic } & \multirow{2}{*}{ No. of women tested ${ }^{a}$} & \multicolumn{2}{|c|}{ Rubella seroprevalence } & \multirow{2}{*}{ P value } \\
\hline & & No. & $\%$ & \\
\hline \multicolumn{5}{|l|}{ Age groups (years) } \\
\hline $15-24$ & 61 & 60 & 98.4 & 0.01 \\
\hline $25-34$ & 159 & 157 & 98.7 & \\
\hline $35-43$ & 59 & 54 & 91.5 & \\
\hline \multicolumn{5}{|l|}{ Birth place } \\
\hline Durango State & 259 & 252 & 97.3 & 1.00 \\
\hline Other Mexican State & 16 & 16 & 100.0 & \\
\hline \multicolumn{5}{|l|}{ Residence place } \\
\hline Durango State & 278 & 270 & 97.1 & 1.00 \\
\hline Other Mexican State & 1 & 1 & 100.0 & \\
\hline \multicolumn{5}{|l|}{ Residence area } \\
\hline Urban & 264 & 257 & 97.3 & 0.42 \\
\hline Suburban & 4 & 4 & 100.0 & \\
\hline Rural & 11 & 10 & 90.9 & \\
\hline \multicolumn{5}{|l|}{ Educational level } \\
\hline Up to 6 years & 1 & 1 & 100.0 & 0.30 \\
\hline $7-12$ years & 102 & 97 & 95.1 & \\
\hline 13 or more years & 176 & 173 & 98.3 & \\
\hline \multicolumn{5}{|l|}{ Occupation } \\
\hline Unemployed $^{\mathrm{b}}$ & 81 & 78 & 96.3 & 0.69 \\
\hline Employed $^{\mathrm{c}}$ & 198 & 193 & 97.5 & \\
\hline \multicolumn{5}{|l|}{ Socioeconomic level } \\
\hline Low & 15 & 13 & 86.7 & 0.02 \\
\hline Medium & 257 & 252 & 98.1 & \\
\hline High & 3 & 3 & 100.0 & \\
\hline
\end{tabular}

aSums may not add up to 279 because of some missing values. bUnemployed: none occupation, student or housewife. ' Employed: employee, professional, business, or other.

including traveling abroad, alcohol consumption, tobacco use, and washing hands before eating did not show an association with rubella seroprevalence.

Multivariate analysis of socio-demographic, clinical and behavioral variables with $\mathrm{P}$ values $\leq 0.05$ by bivariate analysis including age, socioeconomic status, frequent headache, number of deliveries, and national trips showed that seroreactivity to rubella was positively associated only with national trips $(\mathrm{OR}=7.39 ; 95 \% \mathrm{CI}: 1.41-38.78 ; \mathrm{P}=0.01)$, and negatively associated only with age $(\mathrm{OR}=0.26 ; 95 \% \mathrm{CI}: 0.06-0.99 ; \mathrm{P}$ $=0.04$ ).

\section{Discussion}

Very little is known about the serological status against rubella virus in pregnant women in Mexico. Therefore, this study aimed to determine the seroprevalence of $\operatorname{IgG}$ and $\operatorname{IgM}$ anti- bodies against rubella virus in pregnant women in the northern Mexican city of Durango. Results indicate that $97.1 \%$ of the pregnant women studied had protective $(\geq 15 \mathrm{IU} / \mathrm{mL})$ antibodies against rubella virus infection. In Mexico, vaccination against rubella started in 1998 [18]. Although the majority of pregnant women tested had protective antibodies, nearly $3 \%$ of women were susceptible to rubella. This figure seems low but considering that there are nearly 40,000 births a year in Durango State (http://cuentame.inegi.org.mx/monografias/ informacion/dur/poblacion/dinamica.aspx?tema=me\&e $=10$ ), thus there are about 1,200 pregnant women susceptible to rubella virus just in this Mexican state. Concerning studies in Mexico, the seroprevalence of rubella found in the present study is higher than the $87 \%$ seroprevalence of rubella in early puerperium women in the northern Mexican city of Delicias, Chihuahua [12], the $92.6 \%$ seroprevalence of rubella in pregnant women from Iztapalapa and Nezahualcoyotl areas in the valley of Mexico [13], and the $71 \%$ seroprevalence in women 
Table 2. Bivariate Analysis of Clinical Data and Seropositivity to Rubella Virus in Pregnant Women in Durango City, Mexico

\begin{tabular}{|c|c|c|c|c|}
\hline \multirow{2}{*}{ Characteristic } & \multirow{2}{*}{ No. of women tested ${ }^{a}$} & \multicolumn{2}{|c|}{ Rubella prevalence } & \multirow{2}{*}{ P value } \\
\hline & & No. & $\%$ & \\
\hline \multicolumn{5}{|l|}{ Clinical status } \\
\hline Healthy & 267 & 260 & 97.4 & 0.27 \\
\hline Ill & 11 & 10 & 90.9 & \\
\hline \multicolumn{5}{|c|}{ Lymphadenopathy ever } \\
\hline Yes & 42 & 41 & 97.6 & 1.00 \\
\hline No & 237 & 230 & 97.0 & \\
\hline \multicolumn{5}{|c|}{ Headache frequently } \\
\hline Yes & 112 & 112 & 100.0 & 0.02 \\
\hline No & 167 & 159 & 95.2 & \\
\hline \multicolumn{5}{|c|}{ Memory impairment } \\
\hline Yes & 63 & 63 & 100.0 & 0.20 \\
\hline No & 216 & 208 & 96.3 & \\
\hline \multicolumn{5}{|c|}{ Hearing impairment } \\
\hline Yes & 20 & 20 & 100.0 & 1.00 \\
\hline No & 259 & 251 & 96.9 & \\
\hline \multicolumn{5}{|l|}{ Visual impairment } \\
\hline Yes & 79 & 76 & 96.2 & 0.69 \\
\hline No & 199 & 194 & 97.5 & \\
\hline \multicolumn{5}{|l|}{ Blood transfusion } \\
\hline Yes & 13 & 12 & 92.3 & 0.32 \\
\hline No & 265 & 258 & 97.4 & \\
\hline \multicolumn{5}{|l|}{ Pregnancies } \\
\hline One & 89 & 89 & 100.0 & 0.11 \\
\hline Two & 97 & 93 & 95.9 & \\
\hline Three & 50 & 49 & 98.0 & \\
\hline Four & 31 & 28 & 90.3 & \\
\hline Five & 9 & 9 & 100.0 & \\
\hline More than 5 & 2 & 2 & 100.0 & \\
\hline \multicolumn{5}{|l|}{ Deliveries } \\
\hline Zero & 157 & 153 & 97.5 & 0.05 \\
\hline One & 65 & 63 & 96.9 & \\
\hline Two & 41 & 41 & 100.0 & \\
\hline Three & 11 & 9 & 81.8 & \\
\hline Four & 3 & 3 & 100.0 & \\
\hline More than 4 & 1 & 1 & 100.0 & \\
\hline \multicolumn{5}{|l|}{ Cesarean sections } \\
\hline Zero & 195 & 189 & 96.9 & 0.72 \\
\hline One & 62 & 61 & 98.4 & \\
\hline Two & 21 & 20 & 95.2 & \\
\hline \multicolumn{5}{|l|}{ Miscarriages } \\
\hline Zero & 223 & 217 & 97.3 & 0.88 \\
\hline One & 46 & 44 & 95.7 & \\
\hline Two & 8 & 8 & 100.0 & \\
\hline Three & 1 & 1 & 100.0 & \\
\hline \multicolumn{5}{|c|}{ Month of pregnancy } \\
\hline $1-3$ & 100.0 & 98 & 98.0 & 0.1 \\
\hline $4-6$ & 118 & 116 & 98.3 & \\
\hline $7-9$ & 56 & 52 & 92.9 & \\
\hline
\end{tabular}

aSums may not add up to 279 because of some missing values. 
of reproductive age in Leon, Guanajuato [14]. However, this comparison should be taken with care since these studies were performed in different years and laboratory tests used were different from the tests we used. Previous seroprevalence studies in Mexico were performed from 1993 to 2004. In those years, the coverage of rubella vaccination was lower than the one in the recent years. We used ELFA to detect IgG antibodies against rubella virus, whereas in the previous studies, the hemagglutination inhibition method $[13,14]$ was used. In addition, we studied pregnant women in the urban city of Durango, whereas rural and urban women were enrolled in the study in Delicias, Chihuahua [12]. In an international context, the seroprevalence of rubella in pregnant women in Durango is higher than the $93.1 \%$ seroprevalence of rubella found in pregnant women seen in a tertiary hospital in Zaria, Nigeria [19], and $87.5 \%$ seroprevalence in pregnant women in Osogbo, Nigeria [20] using enzyme-linked immunosorbent assays. Similarly, our prevalence is higher than the $85.8 \%$ seroprevalence reported in pregnant women in southern Italy using a microparticle enzyme immunoassay [21]. The rubella seroprevalence found in our study is comparable with the $95.1 \%$ seroprevalence of rubella reported in pregnant women in Sudan [22], the 93.3\% seroprevalence in pregnant women in Portugal [23], the 94.4\% seroprevalence in pregnant women in Oslo, Norway [24], and $95.4 \%$ seroprevalence in women of childbearing age in Venezuelan Yupka indigenous communities [25].

We searched for factors associated with rubella seroprevalence. We found that seroreactivity to rubella was positively associated with national trips and negatively associated with age. International travel has been linked to rubella importation in the USA [26]. We did not find an association of international travel with rubella seropositivity. However, it is possible that rubella exposure occurs also by national trips as results of the present study suggests. Therefore, traveling to high endemic rubella regions should be avoided by pregnant women. In the present study, seroprevalence decreases with age. This fact might reflect the higher coverage of rubella vaccination in young women.

This study has limitations including a small sample size, and enrollment of women in only one clinic of family medicine. Further studies with larger sample sizes and in several clinics to determine the seroprevalence of rubella in Mexican communities should be conducted.

\section{Conclusions}

Rate of rubella immunity in pregnant women in the northern Mexican city of Durango is high. However, nearly 3\% of pregnant women are susceptible to rubella in our setting. Risk factors associated with rubella seropositivity found in this study may be useful for optimal design of preventive measures against rubella and its sequelae.

\section{Conflicts of Interest}

The authors declare that no conflicts of interest exist.

\section{Financial Support}

This study was financially supported by Juarez University of Durango State, Mexico.

\section{References}

1. Stock I. [Rubella (German measles)-still a major infectious disease]. Med Monatsschr Pharm. 2012;35(1):1422; quiz 23-14.

2. Grangeot-Keros L, Bouthry E, Vauloup-Fellous C. [Rubella: a current issue?]. Presse Med. 2014;43(6 Pt 1):698705 .

3. Mori Y, Otsuki N, Sakata M, Okamoto K. [Virology of the family Togaviridae]. Uirusu. 2011;61(2):211-219.

4. Bale JF, Jr. Measles, mumps, rubella, and human parvovirus B19 infections and neurologic disease. Handb Clin Neurol. 2014;121:1345-1353.

5. Lambert N, Strebel P, Orenstein W, Icenogle J, Poland GA. Rubella. Lancet. 2015;385(9984):2297-2307.

6. Nationwide rubella epidemic-Japan, 2013. MMWR Morb Mortal Wkly Rep. 2013;62(23):457-462.

7. Figueroa-Damian R, Ortiz-Ibarra FJ, Arredondo-Garcia JL, Ahued-Ahued JR. [The outcome of pregnancies complicated by rubella, 1990-1997]. Salud Publica Mex. 1999;41(4):271-277.

8. Saraswathy TS, Rozainanee MZ, Asshikin RN, Zainah S. Congenital rubella syndrome: a review of laboratory data from 2002 to 2011. Southeast Asian J Trop Med Public Health. 2013;44(3):429-435.

9. Dewan P, Gupta P. Burden of Congenital Rubella Syndrome (CRS) in India: a systematic review. Indian Pediatr. 2012;49(5):377-399.

10. Solorzano-Santos F, Lopez-Kirwan A, Alvarez y Munoz MT, Miranda-Novales MG, Gadea-Alvarez T, VazquezRosales G. [Congenital rubella syndrome in infants treated at a pediatrics hospital]. Gac Med Mex. 2001;137(2):105109.

11. Sugishita Y, Shimatani N, Katow S, Takahashi T, Hori N. Epidemiological characteristics of rubella and congenital rubella syndrome in the 2012-2013 epidemics in Tokyo, Japan. Jpn J Infect Dis. 2015;68(2):159-165.

12. Sagarnaga Durante D, Delgado Monge C, Saenz Flores G, Tufino Olivares E, Levario Carrillo M. [Frequency of antibodies against rubella virus in puerperium women]. Ginecol Obstet Mex. 2004;72:445-449.

13. Bustamante-Calvillo ME, Damasio-Santana DL, Alvarez-Munoz MT, Munoz-Hernandez O. [Prevalence of rubella virus antibodies in pregnant women in two zones of Valle de Mexico]. Ginecol Obstet Mex. 1996;64:114116.

14. Macias-Hernandez AE, Ponce de Leon S, Munoz-Barrett JM, Lopez-Jimenez F, Cano-Castro A, Vera-Pena A, Aguilar-Orozco G. [The seroepidemiology of rubella in a female population of reproductive age in Leon, Guanajuato]. Salud Publica Mex. 1993;35(4):339-344.

15. Alvarado-Esquivel C, Hernandez-Tinoco J, Sanchez-An- 
guiano LF, Ramos-Nevarez A, Cerrillo-Soto SM, Estrada-Martinez S, Martinez-Ramirez L, et al. Seroepidemiology of cytomegalovirus infection in pregnant women in Durango City, Mexico. BMC Infect Dis. 2014;14:484.

16. Greenwood NP, Ovsyannikova IG, Vierkant RA, O'Byrne MM, Poland GA. A qualitative and quantitative comparison of two rubella virus-specific IgG antibody immunoassays. Viral Immunol. 2010;23(4):353-357.

17. Lai FY, Dover DC, Lee B, Fonseca K, Solomon N, Plitt SS, Jaipaul J, et al. Determining rubella immunity in pregnant Alberta women 2009-2012. Vaccine. 2015;33(5):635641 .

18. Diaz-Ortega JL, Meneses-Reyes CD, Palacios-Martinez M. [Incidence and transmission patterns of rubella in Mexico]. Salud Publica Mex. 2007;49(5):337-344.

19. Olajide OM, Aminu M, Randawa AJ, Adejo DS. Seroprevalence of rubella-specific IgM and IgG antibodies among pregnant women seen in a tertiary hospital in $\mathrm{Ni}$ geria. Int J Womens Health. 2015;7:75-83.

20. Kolawole OM, Anjorin EO, Adekanle DA, Kolawole CF, Durowade KA. Seroprevalence of rubella IgG antibody in pregnant women in osogbo, Nigeria. Int J Prev Med. 2014;5(3):287-292.

21. Calimeri S, Capua A, La Fauci V, Squeri R, Grillo OC,
Lo Giudice D. Prevalence of serum anti-rubella virus antibodies among pregnant women in southern Italy. Int $\mathrm{J}$ Gynaecol Obstet. 2012;116(3):211-213.

22. Adam O, Makkawi T, Kannan A, Osman ME. Seroprevalence of rubella among pregnant women in Khartoum state, Sudan. East Mediterr Health J. 2013;19(9):812-815.

23. Lito D, Francisco T, Salva I, Tavares M, Oliveira R, Neto MT. [TORCH serology and group B Streptococcus screening analysis in the population of a maternity]. Acta Med Port. 2013;26(5):549-554.

24. Barlinn R, Vainio K, Samdal HH, Nordbo SA, Nokleby H, Dudman SG. Susceptibility to cytomegalovirus, parvovirus B19 and age-dependent differences in levels of rubella antibodies among pregnant women. J Med Virol. 2014;86(5):820-826.

25. Monsalve-Castillo FM, Costa-Leon LA, Castellano ME, Suarez A, Atencio RJ. [Prevalence of infectious agents in indigenous women of childbearing age in Venezuela]. Biomedica. 2012;32(4):519-526.

26. Papania MJ, Wallace GS, Rota PA, Icenogle JP, Fiebelkorn AP, Armstrong GL, Reef SE, et al. Elimination of endemic measles, rubella, and congenital rubella syndrome from the Western hemisphere: the US experience. JAMA Pediatr. 2014;168(2):148-155. 